Institute of Animal Husbandry, Department of Nutrition, Gödollo University of Agricultural Sciences, Gødollo, Hungary

PETER PÓTI, SÁNDOR BEDÕ, MIKLÓS MÉZES and JÁNOS TÕZSÉR

\title{
Estimating reproduction ability of Hungarian Merino rams*
}

\section{Summary}

Scrotal circumference, testosterone content of blood serum, libido and sperm quality parameters of Hungarian Merino breeding and young rams were examined according to seasons by the authors in a farm.

In the case of matured rams a seasonal effect was observed both in scrotal circumference and testosterone content of blood serum (measured two hours later after exogenous GnRH treatment) and sperm quality. In the case of young rams no seasonal effect was observed. It was found that the scrotal circumference of young rams and the testosterone content of blood serum (two hours after exogenous GnRH treatment) are determined by the maturity of the rams. A medium connection could be observed between scrotal circumference and testosterone content of blood serum induced by GnRH treatment. In the case of matured rams there is a loose and not significant correlation between scrotal circumference and sperm quality $(r=0.39)$. They have come to the conclusion that libido shows medium correlation with scrotum circumference $(r=0.56)$, while the correlation with testosterone content of blood serum is tight $(\mathrm{r}=0.78)$, and the correlation with sperm quality proves to be a loose one.

According to the results scrotum circumference can be used as one of the possible markers for selection of rams for reproduction purposes.

Key words: rams, merino, scrotal circumference, testosteron, libido, spermquality

\section{Zusammenfassung}

Titel der Arbeit: Die Beurteilung der Reproduktionsfähigkeit bei ungarischen Merinoböcken

Es wurden der Hodenumfang, der Testosterongehalt im Blutserum zwei Stunden nach GnRH-Behandlung, die Libido und die Spermaqualität von Jung- und Zuchtböcken bei ungarischen Merinoschafen in Abhängigkeit von der Jahreszeit untersucht. Im Gegensatz zu den Jungböcken konnte bei den Zuchtböcken ein jahreszeitlicher Einfluß auf den Hodenumfang, den Testosterongehalt im Blut sowie die Spermaqualität nachgewiesen werden. Sowohl beim Hodenumfang als auch dem Testosterongehalt war bei den Jungböcken eine größere Abhängigkeit vom Entwicklungsstand der Tiere festgestellt worden. Zusammenhänge zwischen Hodenumfang und Lebendgewicht bestanden bei beiden Gruppen. Zwischen Hodenumfang und Testosterongehalt wurden mittlere signifikante Korrelationen nachgewiesen. Keine signifikanten, nur tendentielle Zusammenhänge konnten zwischen Hodenumfang oder Testosterongehalt und Spermaqualität bei den Zuchtböcken gefunden werden. Bei dieser Gruppe ergaben sich mittlere Rangkorrelationskoeffizienten zwischen Libido zu Hodenumfang, Testosterongehalt und Spermaqualität. Es wird der Hodenumfang als mögliches Selektionsmerkmal für die Beurteilung der Reproduktionsfähigkeit von Böcken vorgeschlagen.

Schlüsselwörter: Merinoböcke, Hodenumfang, Testosterongehalt, Libido, Spermaqualität

\section{Introduction}

Evaluating the reproduction ability of rams and the relating characteristics (sperm quality, libido) is a basic criteria as for not taking them into consideration can cause considerable loss of profitability.

- This study is sponsored by OTKA 5448 grant. 
Many authors have earlier been dealing with the size and development of scrotal circumference of live animals

THWAITES (1995) weighed the testis of matured Merino rams when examining them. FERNANDES - ABBELA et al. (1993) calculated the volume of scrotum sac both in case of breeding rams and growing rams.

For defining the testis measuring the scrotum crrcumference is generally used by many authors (THOMPSON, 1985; YARNEY et al., 1990, MUCSI, 1991. THOMPSON (1985) considers to state scrotum circumference very important, because seasonal reproduction capacity, the possible infertility and offsprings can be estimated from its size.

YARNEY et al. (1990) were examining the scrotal sac circumference and testis diameter and sperm quality of suffolk rams. It was found among others that sperm quality is better concerning rams with bigger testis (150-190 days and 13 months) than with rams of smaller testis. They traced close and medium strong correlation between testis size and sperm numbers and between testis size and living sperm numbers $(\mathrm{r}=0.61, \mathrm{r}=0.55)$. Similar findings were published concerning rams by MUCSI (1991), DEMIRCI (1993), VALENTIM et al. (1996), SARLÓS et al. (1996). When evaluating MUCSI (1991) calls attention to seasonal effects (seasonal, out-of seasonal periods). He suggests keeping the rams whose mature scrotal sac circumference is at least 36 $\mathrm{cm}, 60-70 \%$ of sperms are moving ahead or $80-90 \%$ of them is morphologically sound. The optimal September-October scrotal sac circumference of breeding ram candidates is at least $30 \mathrm{~cm}$. Similar results are published by RAADSMA and EDEY (1985) and UDALA et al. (1990) concerning the characteristics of ram ejaculate and sizes of testicles or the importance of breeding season.

According to LAND (1983) and MUCSI (1991) from the bigger scrotal circumference an earlier sexual maturity can be concluded.

Beside the testicular size characteristics of libido and the correlation between scrotum circumference and libido have also been observed by more authors. WAHID and YUNUS (1994), YARNEY et al. (1990) found correlation between scrotum circumference and libido of rams when examining the libido of breeding rams, which was calculated by the numbers of ram's coverings during limited time. They aimed that the libido of rams with higher testis (scrotum circumference) is better than those of having smaller testis.

Besides examining testis and libido of rams many experts have made observations concerning sperm producing capacity, quality and their correlation with testis measurement. WAHID and YUNUS (1994) found positive significant correlation between scrotum circumference and sperm quality (motility, concentration) when examining more species of rams (malin, siamese longtail, dorset, suffolk, merino $\mathrm{x}$ border leicester). Similar results were got concerning scrotum circumference. Two species showed the closest connection : malin and siamese longtail. During examining scrotum circumference and sperm production capacity of Awassi rams DEMIRCI (1993) found strong significant $(r=0.98)$ connection. Similar results were published by RAADSHA and EDEY (1985) and UDALA et al. (1990) between ejaculation and 
testis sizes. AKSOY et al. (1994) divided 9 merino rams into three groups based on scrotum sac volumes: $300-500,500-600,700-900 \mathrm{~cm}^{3}$. There were deviations, but not significant ones in sperm capacity between groups.

Beside the testicular size characteristics of the normal hormonal features have also been observed as reproduction indices by more authors (BECZE, 1983, WEKERLE et al., 1989). The examinations were focused on the determination of actual testosterone concentration of blood serum and GnRH induced testosterone release. These examinations are essential because continuous and undisturbed spermatogenesis process a continuopusly high performance of testosterone production is needed (BECZE, 1983).

YARNEY et al (1990) observed scrotum circumference and testosterone content of blood serum of suffolk rams during periods of 20 days. Testosterone content of blood serum was determined by samples got in every 20 minutes during 6 hours. It has been stated among others that testis sizes and spermatogenetic functions of 150 days old and one year old rams are in correlation with LH and testosterone content of blood serum, and scrotum circumference and sperm capacity of 150 days old rams.

During our examinations we were trying to find answers for the following questions:

How scrotal circumference and testosterone content of blood serum and sperm quality change according to seasons?

How age and weight influence testis development and testosterone content of blood serum of young rams?

What kind of correlation can be seen among scrotum circumference, testosterone content of blood serum, libido and sperm quality of rams?

\section{Material and Method}

The scrotal circumference of breeding $(n=20)$ and young rams $(n=30)$ of Hungarian Merino types were measured monthly. The circumference of scrotal sac was measured in the widest part of scrotum according to the methods of BRINKS (1987) and MUCSI (1991).

The GnRH test was carried out using the method of POST (1978) and POST et al. (1987). Blood was taken from jugular vein before and after two hours of GnRH treatment $\left(0.25 \mu \mathrm{g} / \mathrm{kg}\right.$ body weight ${ }^{6} \mathrm{D}-\mathrm{Phe} \mathrm{GnRH}$, Ovurelin inj., REANAL, Budapest). Then from blood serum the testosterone content was determined with direct ${ }^{125}$ I radio immunoassay using steroid free serum as matrix correction (Institute of Isotopes Ltd., Budapest). The assay measurement parameters are: T/Bo: 0.39, NSB/Bo: 0.036, intraassay $\mathrm{cv} \%$ : 5.6, inter-assay $\mathrm{cv} \%: 9.1$. Sensitivity: $0.5 \mathrm{nmol} /$ liter, cross activity: testosterone $100 \% 5 \alpha$-dihydrotestosterone $35 \%, 5 \beta$ - dihydrotestosterone $0.8 \%$.

The libido of rams was decided to use six categories:

1. the ram jumped and ejaculated within 30 seconds,

2. the rams jumped and ejaculated between 30-60 seconds,

3. between $60-90$ seconds,

4. between 90-120 seconds, 
5. the rams jumped and ejaculated beyond 120 seconds.

6. the rams, that didn't jump and didn't ejaculate fell into group 6.

Sperm quality analysis was carried out by traditional (subjective) and instrumental (objective) ways. Sperm taking and qualifying process were done three times in September, January and May. The instrumental analysis was done with diluted sperm samples using HTM sperm analyzer, in the laboratory of OMTV Ltd. (Gögöllö Nagyremete), 1.5 - 2 hours after sample taking. Dilution was done in 1:1 rate with Triladyl - TRIS based diluent.

The following correlation was used for making sperm taking easier both in case of traditional and instrumental qualification:

where:

$$
\mathrm{SM}=100+\left(\frac{\left(\mathrm{A}_{1}-\overline{\mathrm{A}}\right)}{\mathrm{SD}_{\mathrm{A}}}+\frac{\left(\mathrm{B}_{1}+\overline{\mathrm{B}}\right)}{\mathrm{SD}_{\mathrm{B}}}+\frac{\left(\mathrm{C}_{1}+\overline{\mathrm{C}}\right)}{\mathrm{SD}_{\mathrm{C}}}\right) \times 5
$$

$\mathrm{SM}=$ scores for qualifying sperm quality

$A_{1}, B_{2}, C_{1}=$ value of the examined group individuals in the given quality characters

$\mathrm{A}, \mathrm{B}, \mathrm{C}=$ average performance of the examined individuals in the given quality characters

$\mathrm{SD}_{\mathrm{A}}, \mathrm{SD}_{\mathrm{B}}, \mathrm{SD}_{\mathrm{C}}=$ spread value of the given character

$1 \mathrm{SD}=5$ scores

According to the calculation method the individuals reaching more than 100 score can have developing influence, while the individuals reaching less than 100 score can be evaluating as ones having bad influence. The total value of rams showing developing influence goes over 105 .

Analysis of variance and correlation calculation were used for evaluating the data. Microsoft Excel 7.0 software was used for the data processing.

\section{Results and Discussion}

Changes of scrotal circumferences of the years 1994 - 1995 are summarized in Table 1.

Table 1

Seasonal changes of scrotal circumference in breeding and growing rams (Jahreszeitlicher Einfluß auf den Hodenumfang von Zucht- und Jungböcken)

\begin{tabular}{ccccccc}
\hline \multirow{2}{*}{ month } & \multicolumn{5}{c}{ scrotal circumference $(\mathrm{cm})$} \\
& $\mathrm{n}$ & $\begin{array}{c}\text { Mreeding ram } \\
\text { Mean }\end{array}$ & $\pm \mathrm{SD}$ & $\mathrm{n}$ & growing ram \\
Mean & \pm SD \\
\hline September & 20 & 34.91 & 1.92 & 30 & 22.45 & 2.50 \\
January & 20 & 33.55 & 2.86 & 30 & 27.11 & 2.09 \\
May & 20 & 32.59 & 3.25 & 130 & 28.61 & 2.92 \\
\hline
\end{tabular}

By January the average scrotal circumference of breeding rams decreased to $33.55 \mathrm{~cm}$ from the September value of $34.91(\mathrm{p}<0.01)$, and it was the smallest in May, $32.59 \mathrm{~cm}$ $(\mathrm{p}<0.05)$. Similar statements have earlier been done by MUCSI $(1991)$ and PÓTI et al. (1994). MUCSI (1991) reported about 1-3 cm scrotal circumference changes during the year. From Table 1 it can also been seen that scrotal circumference of growing 
rams continually increases probably with continuous growth of animal. In September the average scrotal circumference was $22.45 \mathrm{~cm}$, in January it was already $27.11 \mathrm{~cm}$ and in May $28.61 \mathrm{~cm}$. The possible seasonal changes of scrotal circumference in the case of young overlapped by the growth effect. It is proved by the fact that in the case of young rams there is quite close correlation between their live weight and scrotal circumference $(1994: \mathrm{r}=0.75,1995: \mathrm{r}=0.54)$.

The testosterone content of blood serum shows seasonal changing similarly to scrotal circumference (Table 2).

Table 2

Changes of testosterone content of blood serum before and two hours after GnRH treatment in breeding and growing rams (Veränderung des Testosterongehaltes im Blutserum vor und nach einer GnRH-Bhandlung bei Zucht- und Jungböcken)

\begin{tabular}{|c|c|c|c|c|c|c|c|c|c|c|}
\hline \multirow{4}{*}{ month } & \multicolumn{10}{|c|}{ testosterone content of blood serum (nmol/l) } \\
\hline & \multirow[b]{3}{*}{$\mathrm{n}$} & \multicolumn{4}{|c|}{ in breeding rams } & \multicolumn{5}{|c|}{ in growing rams } \\
\hline & & \multicolumn{2}{|c|}{$\begin{array}{l}\text { before GnRH } \\
\text { treatment }\end{array}$} & \multicolumn{2}{|c|}{$\begin{array}{c}\text { after } \mathrm{GnRH} \\
\text { treatment }\end{array}$} & \multirow[b]{2}{*}{$\mathrm{n}$} & \multicolumn{2}{|c|}{$\begin{array}{l}\text { before GnRH } \\
\text { treatment }\end{array}$} & \multicolumn{2}{|c|}{$\begin{array}{c}\text { after } \mathrm{GnRH} \\
\text { treatment }\end{array}$} \\
\hline & & Mean & \pm SD & Mean & $\pm \mathrm{SD}$ & & Mean & $\pm \mathrm{SD}$ & Mean & $\pm \mathrm{SD}$ \\
\hline September & 20 & 4.88 & 1.46 & 28.65 & 7.12 & 30 & 2.91 & 0.78 & 15.34 & 6.36 \\
\hline January & 20 & 4.07 & 1.01 & 22.92 & 4.61 & 30 & 2.85 & 1.05 & 17.31 & 4.28 \\
\hline May & 20 & 6.47 & 1.73 & 20.45 & 3.77 & 30 & 3.56 & 1.26 & 19.26 & 5.27 \\
\hline
\end{tabular}

In the case of breeding rams both the initial testosterone level and the level after GnRH treatment is higher in September $(x=4.88 \mathrm{nmol} / \mathrm{l}$ and $28.65 \mathrm{nmol} / \mathrm{l})$ than in January $(\mathrm{x}$ $=4.07$ and $22.92 \mathrm{nmol} / \mathrm{l}$ ) then in May though the basic level increases comparing to the two previous periods by $x=6.47 \mathrm{nmol} / \mathrm{l}$, after the treatment it reaches only 20.45 $\mathrm{nmol} / \mathrm{l}$ quantity, which is under the average value of the two previous periods. On the contrary in the case of the young rams the testosterone level of blood serum continually increases (Table 2) and around the age of one it reaches the value of the same period of mature age. As for the scrotum circumference the values of mature age are reached by the growing rams later, about the age of one and half a year.

On the basis of the results it can be stated that seasons have influence on initial and GnRH induced testosterone production of breeding rams, while this influence cannot be seen in the case of young rams. In the later case the maturity and live weight of rams are determining.

There is a medium significant correlation between scrotum circumference and testosterone content measured two hours after GnRH treatment $(r=0.4 \mathrm{P}<0.5)$. There have been different results published concerning this question. YARNEY et al. (1990) got significant correlation $(\mathrm{r}=0.69)$ between testosterone content of blood serum and testis sizes when examining suffolk rams. On the contrary SANFORD (1987), SCHOEMAN et al. (1987) did not find any correlation in their experiments between the average testosterone level and scrotum sac sizes.

It can be stated that $75 \%$ of breeding rams belong to categories 2, 3 and 4 and most of them fell into category 3 during examining their libidos (Table 3 ). Only little rate of breeding rams $(10 \%)$ got into categories 1 and 6 . Examining the libido of young rams it can be seen that the results are significantly worse comparing to those of breeding 
rams It can be also observed that evaluating young rams based on their libidos is more difficult than in case of breeding rams.

Table 3

Libido of rams in different years of examination (September) (Libido der Böcke in verschiedenen Untersuchungsjahren, Monat September)

\begin{tabular}{|c|c|c|c|c|c|c|c|c|c|c|c|c|}
\hline \multirow[t]{3}{*}{ year } & \multicolumn{12}{|c|}{ categories } \\
\hline & \multicolumn{2}{|c|}{1} & \multicolumn{2}{|c|}{2} & \multicolumn{2}{|c|}{3} & \multicolumn{2}{|c|}{4} & \multicolumn{2}{|c|}{5} & \multicolumn{2}{|c|}{6} \\
\hline & $\mathrm{n}$ & $\%$ & $\mathrm{n}$ & $\%$ & $\mathrm{n}$ & $\%$ & $\mathrm{n}$ & $\%$ & $\mathbf{n}$ & $\%$ & $\mathrm{n}$ & $\%$ \\
\hline $\begin{array}{l}\text { breeding } \\
\text { rams }\end{array}$ & 2 & 10 & 4 & 20 & 7 & 35 & 4 & 20 & 1 & 5 & 2 & 10 \\
\hline $\begin{array}{l}\text { growing } \\
\text { rams }\end{array}$ & - & 0 & - & 0 & 1 & 2,8 & 6 & 17.2 & 14 & 40 & 14 & 40 \\
\hline
\end{tabular}

For identifying correlation between libido and scrotum circumference we used rank correlation method. On the basis it can be stated that there is medium correlation $(\mathrm{r}=0.56)$ between libido and scrotum circumference. YARNEY et al. (1990), WAHID and YUNUS (1994), YARNEY et al. (1990) also found correlation between scrotum circumference and libido of rams. They stated that the libido of rams with bigger testis (scrotum circumference) is better than that of the rams with smaller testis.

Results of sperm quality of breeding rams are shown in Table 4.

Table 4

Seasonal effect on some sperm quality parameters (Jahreszeitlicher Einfluß auf einige Spermaqualitätsparameter)

\begin{tabular}{ccccc}
\hline month & & $\begin{array}{c}\text { number of sperm cells } \\
10^{6} / \mathrm{ml}\end{array}$ & $\begin{array}{c}\text { speed } \\
\mu \mathrm{m} / \mathrm{sec} .\end{array}$ & $\begin{array}{c}\text { forward movement } \\
\%\end{array}$ \\
\hline September & $\overline{\mathrm{x}}$ & 685.49 & 83.00 & 70.17 \\
January & $\pm \mathrm{SD}$ & 109.25 & 8.68 & 3.19 \\
& $\overline{\mathrm{x}}$ & 651.28 & 81.83 & 68.25 \\
May & $\pm \mathrm{SD}$ & 105.79 & 5.98 & 5.19 \\
& $\mathrm{x}$ & 579.12 & 73.50 & 62.33 \\
& $\pm \mathrm{SD}$ & 115.70 & 6.63 & 3.31 \\
\hline
\end{tabular}

It is possible to compare the sperm samples taken in different periods of the year because sperm taking was carried out regularly during the examination period.

In the case of examination the average quality of sperm samples (number of sperm cells, speed of forward movement, \%) taken in three different periods decreases from September to May. The average number of sperms in September was 685.49 million and in January it was 651.28 million, and in May 579.12 million per millilitres. The moving speed of sperm samples and the rate of the forward moving sperms decreased from September to May.

For making the qualifying of sperm samples easier we used in the case the correlation mentioned in material and method part of this study.

This method facilitates ranking of the sperm samples and can be used by the breeders (Table 5).

The same six rams proved to have quite developing influence during the examined period of time: in September their average result was 112.96 scores, in January it was 
Arch. Tierz. 42 (1999) 5

Table 5

Rank order of rams based on sperm qualification (Rangordnung der Böcke nach ihrer Spermaqualität)

\begin{tabular}{|c|c|c|c|c|c|c|}
\hline \multirow[t]{2}{*}{$\begin{array}{c}\text { ram } \\
\text { categories }\end{array}$} & \multicolumn{2}{|c|}{$\begin{array}{l}\text { September } \\
\text { (2) }\end{array}$} & \multicolumn{2}{|r|}{$\begin{array}{c}\text { January } \\
\text { (3) }\end{array}$} & \multicolumn{2}{|r|}{$\begin{array}{l}\text { May } \\
\text { (4) }\end{array}$} \\
\hline & $\mathrm{n}$ & average-SD & $\mathrm{n}$ & average-SD & $\mathrm{n}$ & average-SD \\
\hline $\begin{array}{l}\text { definitely } \\
\text { increasing }\end{array}$ & 6 & $112.96 \pm 4.39$ & 6 & $114.42 \pm 2.43$ & 6 & $114.60 \pm 2.39$ \\
\hline increasing & 4 & $103.65 \pm 0.35$ & $4^{\circ}$ & $102.40 \pm 1.59$ & $4^{\circ}$ & $102.46 \pm 0.98$ \\
\hline decreasing & 10 & $90.04 \pm 7.37$ & $10^{\circ}$ & $89.59 \pm 5.97$ & $10^{\circ}$ & $89.45 \pm 5.78$ \\
\hline
\end{tabular}

114.42 scores, in May it was 114.60 scores (Table 4). Out of the rest of 14 rams two proved to have increasing influence in the three examined period, while one of the two got 103.89 scores in September and the other 103.52 scores in January, and 107.77 scores in May.

Taking sperm from rams and the qualification has been done by traditional methods during two occasions in the age of 7-8 and 11-12 months. When using the traditional method we examined mass moving, density And living cell percentage of sperms (Table 6).

Table 6

Sperm quality of growing rams (Spermaqualität bei den Jungböcken)

\begin{tabular}{ccccc}
\hline age of rams & $\mathrm{n}$ & $\begin{array}{c}\text { mass-moving } \\
1-5 \text { point }\end{array}$ & $\begin{array}{c}\text { density } \\
10^{6} \mathrm{~mm}^{3} \\
\overline{\mathrm{x}} \pm \mathrm{SD}\end{array}$ & $\begin{array}{c}\text { living sell } \\
\%\end{array}$ \\
months & & $\overline{\mathrm{x}} \pm \mathrm{SD}$ & $\overline{\mathrm{x}} \pm \mathrm{SD}$ \\
\hline $7-8$ & 16 & $3.42 \pm 0.73$ & $1.32 \pm 0.66$ & $52.2 \pm 18$ \\
$11-12$ & 30 & $4.25 \pm 0.85$ & $1.38 \pm 0.64$ & $73.8 \pm 18$ \\
\hline
\end{tabular}

The results in the table show that sperm quality is better in older age (11-12 months), scattering is less comparing to the younger age (7-8 months).

For making the evaluation process easier we used the correlation that was applied in case of breeding rams before. On the basis of the results it can be stated that a usefol rank order for young rams of 7-8- months old cannot be made because of the high scatter value, the non efficient quality and the number of sperm samples, but it is possible to make an order in the age of 11-12 months. When evaluating sperm quality other effects like conditions of keeping and feeding, jumps also have great influence on the results. This can be an explanation why other characteristics like scrotum circumference, testosterone content of blood serum, secondary sex have to be taken into consideration when examining the reproduction capacity of young rams. It has also been provided that there is no correlation between scrotum circumference and sperm quality in the age of 7-8 months, but this value is loose medium $(r=0.41)$ in the age of 11-12 months. In case of young rams the examination of scrotum circumference has been identifiedas a necessary one according to YARNEY et al. (1990): examining scrotum circumference, and diameter and sperm quality of suffolk growing rams they have come to the conclusion that sperm quality of rams with bigger testis (150-190 days old) are better than that of rams with smaller testis. Also sperm content and the rate of living sperms of rams with bigger testis are higher. The correlation between testis sizes and sperm numbers, and the correlation between testis sizes and living 
sperm numbers were medium strong $(\mathrm{r}=0.61, \mathrm{r}=0.55)$. Similar results were published by LUNSTRA (1986) and BRINKS (1987) in case of young bulls.

To determine the connections between scrotal circumference and the other measured characters, or between testosterone content of blood serum and sperm quality regression analysis was carried out annually. To find the correlation between libido and other characteristics (scrotum circumference, testosterone content of blood serum, sperm quality) we used rank correlation. The results of correlation analyses are shown in Table 7.

Table 7

Results of correlation analyses among the different investigated parameters (Ergebnisse der Korrelationsanalyse zwischen den verschiedenen untersuchten Parametern)

\begin{tabular}{|c|c|c|c|c|c|}
\hline parameter & & $\mathrm{n}$ & $\mathbf{r}$ & $r_{\text {rank }}$ & significance \\
\hline scrotal circumference vs. live weight & breeding ram & 20 & 0.61 & - & $\mathrm{P}<0.01$ \\
\hline scrotal circumference vs. live weight & growing ram & 30 & 0.57 & - & $\mathrm{P}<0.01$ \\
\hline $\begin{array}{l}\text { scrotal circumference vs. testosterone after } \mathrm{GnRH} \\
\text { treatment }\end{array}$ & breeding ram & 20 & 0.44 & - & $\mathrm{P}<0.05$ \\
\hline $\begin{array}{l}\text { scrotal circumference vs. testosterone after GnRH } \\
\text { treatment }\end{array}$ & growing ram & 30 & 0.48 & - & $\mathrm{P}<0.05$ \\
\hline scrotal circumference vs. sperm quality & breeding ram & 20 & 0.39 & - & NS \\
\hline $\begin{array}{l}\text { testosterone after GnRH treatment vs. sperm } \\
\text { quality }\end{array}$ & breeding ram & 20 & 0.25 & - & NS \\
\hline scrotum circumference - libido & breeding ram & 20 & - & 0.56 & \\
\hline libido - testosterone after GnRH treatment & breeding ram & 20 & - & 0.78 & \\
\hline libido - sperm quality & breeding ram & 20 & - & 0.45 & \\
\hline
\end{tabular}

It can be stated that both in the case of breeding rams and growing rams there is a medium strong significant correlation between scrotal circumference and live weight $(\mathrm{r}$ $=0.61, \mathrm{r}=0.57$ ), between scrotal circumference and blood serum level measured 2 hours after $\mathrm{GnRH}$ treatment $(\mathrm{r}=0.44, \mathrm{r}=0.48)$. There have been various results published concerning this question. YARNEY et al. (1990) got significant correlation between testosterone content of blood serum and testis size when examining suffolk rams. On the contrary SANFORD (1987) and SCHOEMAN et al. (1987) did not find any correlation between the average testosterone content and scrotum circumference.

On the basis of the results such observation can be made as the loose-medium not significant correlation between scrotal circumference and sperm quality. LUNSTRA (1986), BRINKS (1987), NWAKALOR and EZIMA (1989) found similar results in case of bulls while MUCSI (1991) with rams, where the correlation between scrotal circumference and sperm producing capacity found were just as week or of medium strength as ours. Between libido and circumference medium relation ( $\left.\mathrm{r}_{\text {rank }}=0.56\right)$, between libido and testosterone content of blood serum close positive $\left(r_{\text {rank }}=0.78\right)$ relation can be found. Between sperm quality and libido there is loose relation $\left(r_{\text {rank }}=\right.$ 0.45). Similar results were published by YARNEY et al. (1990).

\section{Conclusions}

1. Seasonal influence both in scrotal circumference and in testosterone content of blood serum (two hours after GnRH treatment) can be observed in the case of 
Arch. Tierz. 42 (1999) 5

mature rams. Whereas scrotal circumference and testosterone content of blood serum (two hours after GnRH treatment) are determined by the maturity of growing rams.

2. The correlation between scrotal circumference and testosterone level of blood serum induced by $\mathrm{GnRH}$ is loose or tight. In case of mature rams this connection is tighter than in the case of growing rams.

3. Libido shows medium relation with scrotum circumference, close relation with testosterone content of blood serum and loose relation with sperm quality.

4. Correlation between scrotum circumference and sperm quality is loose - medium strength.

Scrotum circumference can be as one of the possible markers for selection of the rams for reproduction.

\section{References}

AKSOY, M.; ATAMAN, M.B.; KARACA, F.; KAYA, A.:

Relationships of testis measurements with semen quality in Merino rams. Veteriner Bilimleri Dergisi. 10 (1994) 1-2, 127-129

BECZE J.:

Reproduction of male animals. (In Hungarian). Mezõgazdasági Kiadó, Budapest (1983), 64-79

BRINKS, J.S.

Genetics of reproductive traits in bulls Beef Research. Progress Report 3 (1987), 30-38

DEMIRCI, E.:

Studies on semen characters of Awassi rams, and correlations of semen volume with age and testis size. Veteriner-Fakultesi-Dergisi,-Uludag-Universitesi 12 (1993) 3, 98-106

FERNANDEZ-ABELLA, D.; VILLEGAS, N.; ECHEVERRIA, D.; ROBAINA, J.:

Evaluation of the effects of seasonal variations on semen production in rams of four breeds. BoletinTecnico-de-Ciencias-Biologicas,-Universidad-de-la-Republica,-Salto 3 (1993) 1, 23-34

LAND, R.B.:

Nature, London 241 (1983), 208-209

LUNSTRA, D.D.:

Libido and serving capacity of beef bulls. Proc. Symp. Male Fertil., Beef Improvement Fed. Ann. Meeting, Lexington, 20-30. 1986

MUCSI, I.:

Current Questions of veterinary and productivity in sheep breeding. (In Hungarian). DATE Agricultural College Publications (Föiskolai Kar Tud. Közl.) 1 (1991) ,150-155

NWAKALOR, L.N.; EZINMA, C.O.:

Libido, serving capacity and breeding soundness in Muturn and N'Dama beef bulls. Theriogenology 32 (1989), 901-909

POST, T.B.:

Similarity between episodic testosterone peaks and those induced by GnRH or HCG in bulls. Prod. $10^{\text {th }}$ Ann. Conf. Austr. Soc. Reprod. Biol., Sydney, 60-68. 1978

POST, T.B.; CHRISTENSEN, H.R.; SEIFERT, G.W.:

Reproductive performance and reproductive traits of beef bulls selected for different levels of testosterone to GnRH. Theriogenology, 26 (1987), 205-210

PÓTI, P.; MÉZES, M.; TŐZSÉR, J.; NAGY, A.; BEDŌ, S.:

Relationship between scrotal circumference of growing and adult breeding rams and their testosterone level in blood plasma without and after GnRH-treatment. (In Hungarian). Állattenyésztés és Takarmányozás, Budapest, 43 (1994) 5, 397-406

RAADSMA, H.W.; EDEY, T.N.:

Mating performance of paddock-mated rams. L. Changes in mating performance, ejaculate characteristics and testicular size during the joining period. Anim. Reprod. Sci., Amsterdam 8 (1985) $1 / 2,79-99$ 
SANFORD, L.H.:

Seasonal variation in circulating gonadotropin and testosterone levels and in testis size of yearling rams during and subsequent to immunoneutralization of estradiol or tamoxifen treatment in the nonbreeding season. Can. J. Animal. Sci., Ottawa 67 (1987) 2, 391-404

SARLÓS, P.; MOLNÁR, A.; HUSZÁR, S.; RÁTKY. J.; BRƯSSOW, K.P.:

Seasonal changes of andrological characteristics in British Milk ram. Arch. Tierz., Dummerstorf 39 (1996), 265-275

SCHOEMAN, S.J.; MAREE, C.; COMBRINK, G.C.:

The relationship between testis size and stimulated plasma testosterone concentrations and its influence on mating performance in Dorper rams. South-African-Journal-of-Animal-Sci. 17 (1987) 2, $63-69$

THOMPSON, L.H.: Scrotal circumference. As an important measurement Sheep Breed. Sheepm. Magaz., Columbia, 105
(1985) 7, 26-27

THWAITES, C.J.:

The comparative effects of undernutrition, exercise and frequency of ejaculation on the size and tone of the testes and on semen quality in the ram. Animal Reprod. Sci. 37 (1995) $3-4,299-309$

UDALA, J.; BORYCZKO, Z.; ORDYSINSKA, L.; LOPUSZKO, B.:

Ocena jakosci nasienia tryków rasy merinos w cyklu rocznym. Medycyna Weterynaryjna (Warszawa) 46 (1990), 403-406

VALENTIM, R.C.; AZEVEDO, J.; TEIXEIRA, A.; CORREIA, T.M.; SOARES, V.:

In vivo and postmortem testis measurements in entire and short-scrotum Braganca Galician lambs at 65 and $80 \%$ of adult body weight. (in Portuguese) Veterinaria Tecnica. 6 (1996) 2, 18-21

WAHID, S.A.; YUNUS, J.M.:

Correlation between testicle measurements and libido and semen quality in rams. Asian Australasian Journal of Animal Sciences 7 (1994) 2, 175-178

WEKERLE L.; SZÖLLÕSI E.; BERECZKY V.; VARSZEGI I.; PICHLER A.; HAMAR GY.; FEHÉR L.:

GnRH-test in bulls. (In Hungarian). Magyar Allatorvosok Lapja. 41 (1989), 737-739

YARNEY, T.A.; SANFORD, L.M.; PALMER, W.M.:

Pubertal development of ram lambs: Body weight and testicular size measurements as indices of postpubertal reproductive function. Canadian J. Animal Sci., Ottawa 70 (1990), 139-147

Received: 23.11 .1998

Accepted: 23.04 .1999

Authors' address

Dr. PETER PÓTI, Prof. Dr. SÁNDOR BEDŌ, Dr. MIKLÓS MÉZES, Dr. JÁNOS TŌZSÉR

Institute of Animal Husbandry, Department of Nutrition

Gödöllõ University of Agricultural Sciences

H-2103 G8döllő

Hungary 